REGULAR ARTICLE

\title{
EURO MEMBERSHIP, FOREIGN BANKS AND CREDIT DEVELOPMENTS DURING THE FINANCIAL CRISIS IN SLOVAKIA: A CASE STUDY
}

\author{
Jarko Fidrmuc ${ }^{1 *}$,Andreas Wörgötter ${ }^{2}$
}

\author{
Address: \\ ${ }^{1}$ Zeppelin University, Friedrichshafen, CESifo Munich, and Comenius University Bratislava. \\ ${ }^{2}$ Head of Division V, Country Studies Branch, Economics Department OECD. \\ *Corresponding author: Jarko Fidrmuc, e-mail:jarko.fidrmuc@zu.de
}

\begin{abstract}
Slovakia joined the euro area after a period of unprecedented real appreciation. The response to the financial crisis combined internal devaluation with productivity increasing measures, including capital deepening in the banking sector. Although this strategy was successfully restoring an external equilibrium, the economy experienced a strong but short recession in 2009, which was driven by credit reductions. This development is compared with Estonia and Slovenia, two other small and very open economies that recently entered the euro area. The financial crisis reduced the financial integration gains in new euro member states in Central and Eastern Europe.
\end{abstract}

Keywords: euro adoption, CEECs, crisis, foreign banks, credit crunch, liquidity shortage JEL:E20, F41, G01

\section{INTRODUCTION}

The emerging economies in Central and Eastern European countries (CEECs) have been hit particularly hard by the financial crisis. This is generally viewed as a result of vulnerabilities that have accumulated during the pre-crisis period. Excessive consumption growth was associated with a lending boom, and the credits were provided mainly by foreign banks, which invested massively in CEECs. During the financial crisis this development was negatively affected by several factors. First, several CEECs let their currencies depreciate massively in order to improve competitiveness and deal with capital flight and sudden stops of capital inflows. Second, the growth forecasts for CEECs and especially for private consumption were significantly revised downward.

Both factors have important implications for foreign banks active in CEECs. Luca and Petrova (2008) and Basso et al. (2011) argue that foreign banks used their easier access to international capital markets and foreign funds from their home country for credits in CEECs. The depreciations reduced the foreign currency value of credits provided in East European currencies, thus imposing significant losses to foreign banks. As far as many foreign banks engaged in foreign currency lending, the exchange rate depreciations increased the risk of foreign currency loans (Beckmann, Fidrmuc and Stix, 2012) with similar negative implications on the profits of foreign banks. The financial vulnerability in CEECs was further increased by adverse income shocks of the borrowers.
Accordingly, the loan behaviour of foreign banks has received increasing attention in the academic literature and among economic policy makers. Assessing the overall welfare consequences of foreign lending requires balancing its contribution to growth, in particular in countries with underdeveloped domestic financial markets, against the potential increase of exposure to foreign shocks and contagion. The macroeconomic risks for financial stability arising from foreign lending- e.g. via a currency mismatch on banks' balance sheets, aggregate refinancing problems of banks, the threat of sudden stops - are well understood (Levy Yeyati, 2006).

As a small economy in the process of catching up, entry into the euro area brought about a significant change in the macroeconomic framework for Slovakia. In the run-up to its entry, borrowing costs fell, the exchange rate risk disappeared and the growth outlook for the economy improved (Huefner and Koske, 2008). Together with earlier financial sector privatisation and liberalisation, the introduction of the euro reduced barriers for borrowers (Backé and Wójcik, 2008; Huefner and Koske, 2008). However, in the Slovak case, the international financial crisis aborted the expected boom before it could take hold.

For peripheral euro-area member economies, the financial crisis worsened access to international financial markets because of perceived liquidity problems and contagion effects, which have only recently been taken into account by enlarging the toolkit of the ECB and by establishing a European souvereign debt intervention architecture. Furthermore, the fact that the exchange rate 
is no longer available as a macroeconomic stabilisation tool has raised fears that the country cannot adequately deal with adverse external shocks, thereby becoming more likely to be a victim of contagion.

This paper describes how Slovakia navigated the crisis and how its economy returned to a strong, though jobless, growth. Further insights are provided by a comparison with Estonia and Slovenia, two other countries which have recently adopted the euro. The combination of a sound financial sector, a stabilityoriented macroeconomic policy framework, flexibilityenhancing labour market regulations and competitionfriendly product market regulation are of key importance for a small euro member country to absorb adverse external shocks (Brixiova et al, 2009; Berka et al, 2012). The specific challenge for Slovakia is to replace the historically important, but now fading, external drivers of growth, which have been dependent on largescale FDI plants, with domestic sources of growth, which emphasise innovation and knowledge-intensive start-ups, while utilising and fostering the opportunities of a transition to green growth. At the same time, public finances will need to be brought back to a sustainable path.

Our research builds upon and is related to previous literature. The role of banks' funding in a foreign currency has been dealt with in the theoretical literature (see e.g. the model by Basso et al., 2007, Brown and De Haas, 2010). Another strand of literature focuses on the macroeconomic impact of foreign lending on financial stability (e.g. Levy Yeyati, 2006). Finally, our research is also related to the growing research on foreign lending which employs microdata. While the previous literature was based mainly on aggregate data for individual countries or sectors, the micro-econometric approach provides important insights into the determinants of foreign lending.

\section{FINANCIAL CRISIS AND SLOVAKIA}

The worldwide financial crisis severely affected the Slovak economy. In 2009, GDP declined by 4.9 per cent (Figure 1). This decline was stronger than in other regional economies (growth of 1.6 per cent in Poland, a decline of 4.6 per cent in the Czech Republic in 2009) and the initial shock was larger than in Spain (-3.7 per cent in 2009) and Greece (-3.3 per cent), although it was less dramatic than the output decline in Slovenia ( -7.8 per cent) and in Estonia (-14.3 per cent). However, the Slovak economy recovered as early as 2010 and returned almost to the "normal" pre-boom growth rates of about 4 per cent in 2010 and 2011, exceeding the pre-crisis peak in the second quarter of 2011. This pattern is similar in Estonia, but very different from Slovenia, which experienced only slow growth after 2009 and even another recession since 2012.

Unsurprisingly for a global crisis, foreign trade was hit particularly hard. In 2009 exports fell by about $20 \%$ in Estonia and Slovenia and by $15 \%$ in Slovakia. Imports fell by more than 30\% in Estonia and about 20\% in Slovakia and Slovenia. Net exports therefore supported economic activity, because the slump in domestic demand also hit foreign suppliers. The subsequent export driven recovery was strongest in Estonia, followed by Slovakia, while Slovenia experienced a rather shallow recovery of foreign trade.

Although the origin of the crisis was external, domestic demand took a hard hit as well (Figure 5). The reasons for the dismal performance of domestic demand was manifold. Credit standards were tightened, income growth declined and borrowing costs increased, while the labour market deterioration weighed on consumer confidence and the negative external outlook caused firms to revise their investment plans downward. Last but not least, fiscal consolidation exercised a negative short term effect on domestic demand.

The recession caused a slight increase in nonperforming loans in 2009, which largely stabilised in 2011 (Figure 1). Nevertheless, nonperforming loans remained at 5 per cent of total gross loans, which was below the levels prior to the EU accession. The well capitalised, foreign-owned private banking sector played a helpful role to secure financial stability. This is again similar to Estonia, but in contrast to Slovenia where the domestically owned banking sector had to be recapitalised with public funds (OECD, 2012a).

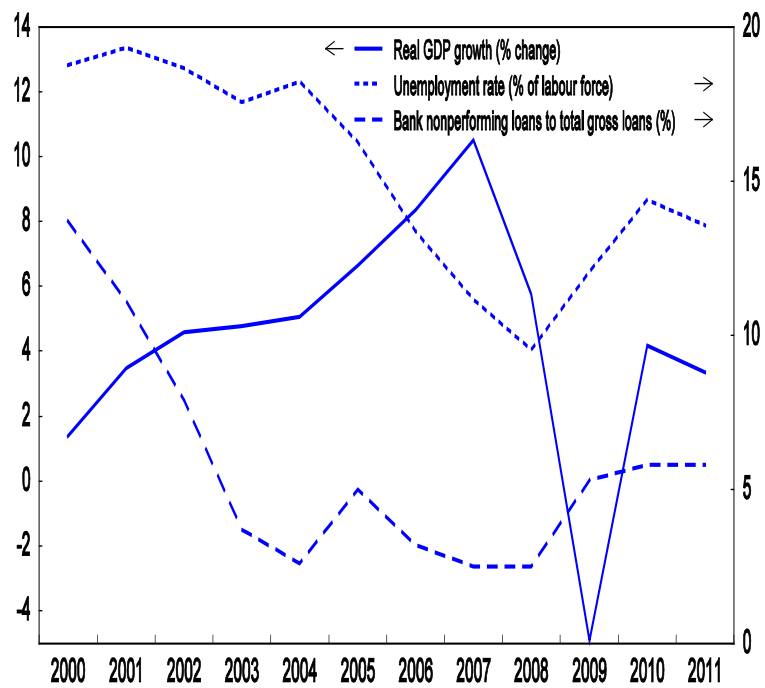

Figure 1. GDP growth, unemployment and non performing loans

Source: OECD Economic Outlook database; World Bank, World Development Indicators database.

\section{FDI inflows}

An active investment promotion policy, business friendly structural reforms, low corporate income taxes and the prospect of euro accession, resulted in a surge in inflows of FDI from the early 2000s. However, the financial crisis reduced the worldwide supply of investment funds, in particular for emerging economies in the EU and euro area (Walch and Wörz, 2012). Furthermore, euro appreciation vis-a-vis the CEECs outside the euro area reduced the relative attractiveness of Slovakia as an investment location for export production. Moreover, frequent legislation changes imposed by new governments and an associated risk of regulatory 
uncertainty in important areas, possibly diverted investors from Slovakia to other emerging economies. FDI actually, fell significantly in 2010 (the remaining inflows concerned mainly equity investments in the financial sector) and remained negligible afterwards. Thus, FDI did not contribute to the recovery from the financial crisis, even though it was an important building stone of the previous growth model (Fidrmuc and Martin, 2011). The successful Slovak business model has thus come under pressure and a new source of stimulus is needed for the continuation of a rapid catchup of the Slovak economy.

The nature of FDI inflows has changed. While in the years before the crisis, FDI flows were dominated by large greenfield investments, since the crisis, investments in existing plants have become more important (Figure 2). These investments have created fewer additional employment opportunities and have been undertaken to defend the viability of existing operations in the face of the strong real appreciation before euro adoption, new competitors in the region and the worse outlook for Slovakia's main export goods (cars and flat screens).

FDI inflows have exerted a strong influence on the Slovak economy. Employment growth was positively correlated with FDI inflows. The real exchange rate has appreciated during the periods of large capital inflows, but the overall effects remained moderate, though positive, up to 2011. Until 2009, FDI inflows and employment growth were increasing as the real exchange rate appreciated, while from 2009 on, the real exchange rate depreciated slightly and employment growth and FDI inflows decelerated.

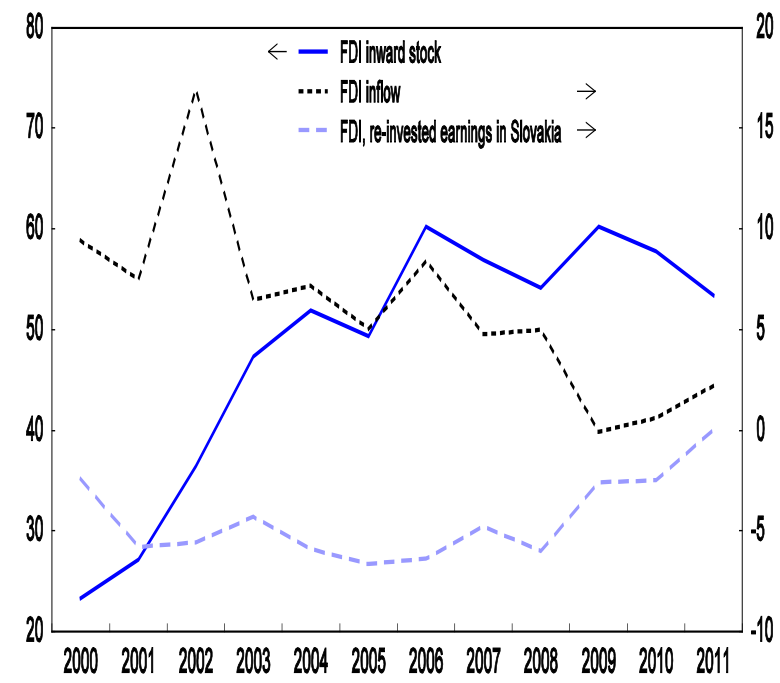

Figure 2. FDI inward flow and stock, and re-invested earnings in Slovakia

Source: OECD, International direct investment database and Eurostat.

Productivity gains were achieved both by new investments and by reduction in low-productivity employment, both contributing to an acceleration of productivity growth in manufacturing. Actually, while industrial employment was roughly constant throughout the 2000s, it continued to fall after the 2009 crisis.
Moreover, productivity and export performance are closely related: FDI inflows (e.g. to sectors such as automotives) appear to be geared to productivity increases and maintaining export competitiveness.

\section{Fiscal and Financial Developments}

As a consequence of budget consolidation, low income growth, stagnating employment, deteriorating terms-oftrade and the increase in servicing costs of loans as a percentage of income, domestic demand growth fell from an average of about $6 \%$ before the crisis by $6 \%$ in 2009 and has not yet reached the pre-crisis level of 2008 .

Before the crisis mortgage loans and other borrowing by private households were facilitated by a large differential between income growth and borrowing costs (Figure 3). Loans were easily financeable out of income increases, without having to sacrifice current consumption. This has changed dramatically since the crisis. Wages stagnated in 2009 and 2010 and with less bright future income prospects, borrowers (and lenders) have become more cautious, increasing the savings rate. Currently servicing old loans means less money is available for current consumption spending and real estate investments. Consequently, the demand for loans has weakened recently.

of

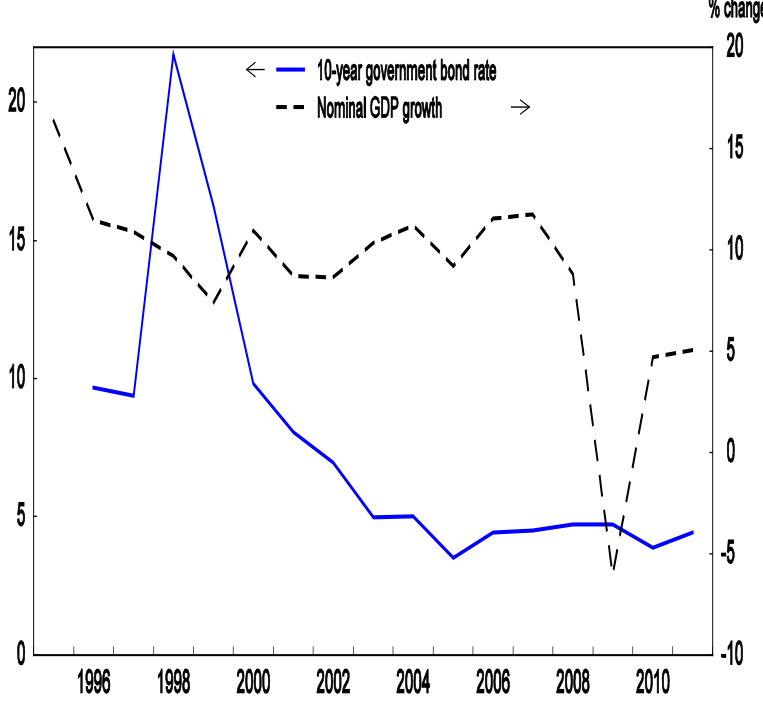

Figure 3. Borrowing costs and nominal GDP increases Source: OECD Economic Outlook database.

Prior to the financial crisis, Slovakia succeeded in reducing public debt levels, while experiencing a favourable development in the relation between borrowing costs and nominal income (Figure 3). The 10year government rate declined from its peak of above 20 per cent in 1998 to below 5 per cent in 2008, while at the same time, nominal GDP growth accelerated from below 10 per cent annually in the late nineties and early 2000s to significantly above 10\% between 2003 and 2007 . Having increased up to the early 2000s, gross public debt then decreased strongly until the crisis hit in 2009 and increased strongly after, although remaining below the level of the beginning of this decade. Despite the strongly falling debt-to-GDP ratio, fiscal policy was too loose during the good times, requiring pro-cyclical tightening at a time when the labour market was already under 
stress. While there is no alternative to public sector consolidation and the private household savings rate is endogenous, it is nevertheless important to organise the return to sustainable public sector balances in a form which is least growth damaging (OECD, 2012b, Chapter 1).

Despite historically low interest rates, due to both the euro introduction and the financial crisis, credit growth was lower than in other CEECs and it further slowed Slovakia at the end of 2011, as the sovereign debt crisis escalated and credit standards were tightened, in particular for consumer credit and real estate mortgages. Lending has more closely been following the development of deposits (Figure 4), as a result of a growing segmentation of financial markets within the EMU since the financial crisis. Before August 2008, the borrowing of households and even more that of firms, was negatively correlated with deposit growth, implying consumption smoothing and increasing access of firms to financial markets. Since the autumn of 2008, deposits and lending to households and firms have, in turn, both shown a correlation of above 0.7 .

As a consequence of a conservative lending policy, the Slovak banking sector is in good shape. According to Barisitz (2011) and UniCredit (2012), non-performing loans are among the lowest in the region. However, several regional financial supervisory institutions have issued macroprudential recommendations, which effectively limit new loans to the stable domestic deposit base. The lack of domestic financial resources may present a significant burden on growth in the coming years. Thus, despite EMU membership, Slovakia could become subject to a possible credit-constrained growth recovery.

Unwinding the pre-euro-entry boom and posteuro-entry bust cycle is made more complicated by the ongoing euro crisis, which brought about a re-pricing of risks and contagion effects on emerging markets in general. The main consequence of the ongoing euro sentiment crisis, is the disruption of financial markets and contagion on sovereign debt markets, in particular for small peripheral catching up economies, even if - as in the case of Slovakia - the fiscal situation is sound.

Since euro entry nominal convergence is limited to the Balassa Samuelson effect, which currently is masked by the extreme cyclical position of the economy with a closed output gap, but a significant unemployment gap. Nominal convergence will therefore be slower than before the crisis and contribute to tighter financial conditions, because of higher real interest rates associated with lower inflation expectations. Égert (2011) estimates that the Samuelson-Balassa effect (related to productivity differences between the traded and non-traded goods sectors) was, at 1.2 to 2.0 percentage points annually, larger in Slovakia than in other new member states of the EU. According to Oomes (2005), a maximum appreciation of up to 3 percentage points annually can be achieved by price changes related to faster productivity improvements in export-oriented manufacturing relative to domestically oriented services.

\section{Regression analysis}

We document the increasing segmentation of financial markets in the euro area and in particular the disconnection of Slovak credits from abroad by the following regression of relationship between credit and deposit growth,

$$
\dot{k}_{t}=\beta_{1}+\beta_{2} \dot{d}_{t}+\beta_{3} \text { crisis }_{t}+\beta_{4} \text { crisis }_{t} \times \dot{d}_{t}+\varepsilon_{t}
$$

where $k$ and $d$ denote contribution to the annual growth of credits and deposits, and crisis is a dummy variable for the period of the financial crisis (September 2008 to May 2012). We estimate this relationship for total credits, as well as for credits to non-financial corporations and households. All specifications use growth of total deposits and the explanatory variable.

The estimations in Table 1 confirm that Slovakia was well integrated into the international financial markets before the financial crisis. In particular, deposits did not play a significant role for the determination of the domestic credit development. This has changed since the collapse of the Lehman brothers in September 2008. On the one hand, credit growth slowed down in all market segments. On the other hand, and more importantly, total credit growth and growth contribution of credits to nonfinancial corporations depend significantly on the development of domestic deposits.

\section{INTERACTIONS BETWEEN EURO ADOPTION AND THE CRISIS}

Although the 2009 crisis was a common factor, economic developments in Slovakia have been different from other recently-joining, small euro area member countries (Figure 5). As elsewhere, GDP fell significantly; yet, contrary to Slovenia and Estonia, the recovery was forceful enough to bring the GDP back to its pre-crisis level in 2011. However, the labour market reaction has been very strong in Estonia, where the unemployment rate has fallen, and relatively weak in Slovenia, where it has continued rising, while developments in Slovakia have been in-between, as unemployment has been stuck at high levels. What is not immediately clear, is what caused the occurrence of a jobless recovery with relatively high rates of GDP growth in Slovakia and the nature of the constraints the country faces for increasing the job-richness of the ongoing strong recovery.

Productivity gains were achieved both by new investments and by reduction in low-productivity employment, both contributing to an acceleration of productivity growth in manufacturing. Actually, while industrial employment was roughly constant throughout the 2000s, it continued to fall after the 2009 crisis. Moreover, productivity and export performance are closely related: FDI inflows (e.g. to sectors such as automotives) appear to be geared to productivity increases and maintaining export competitiveness. 

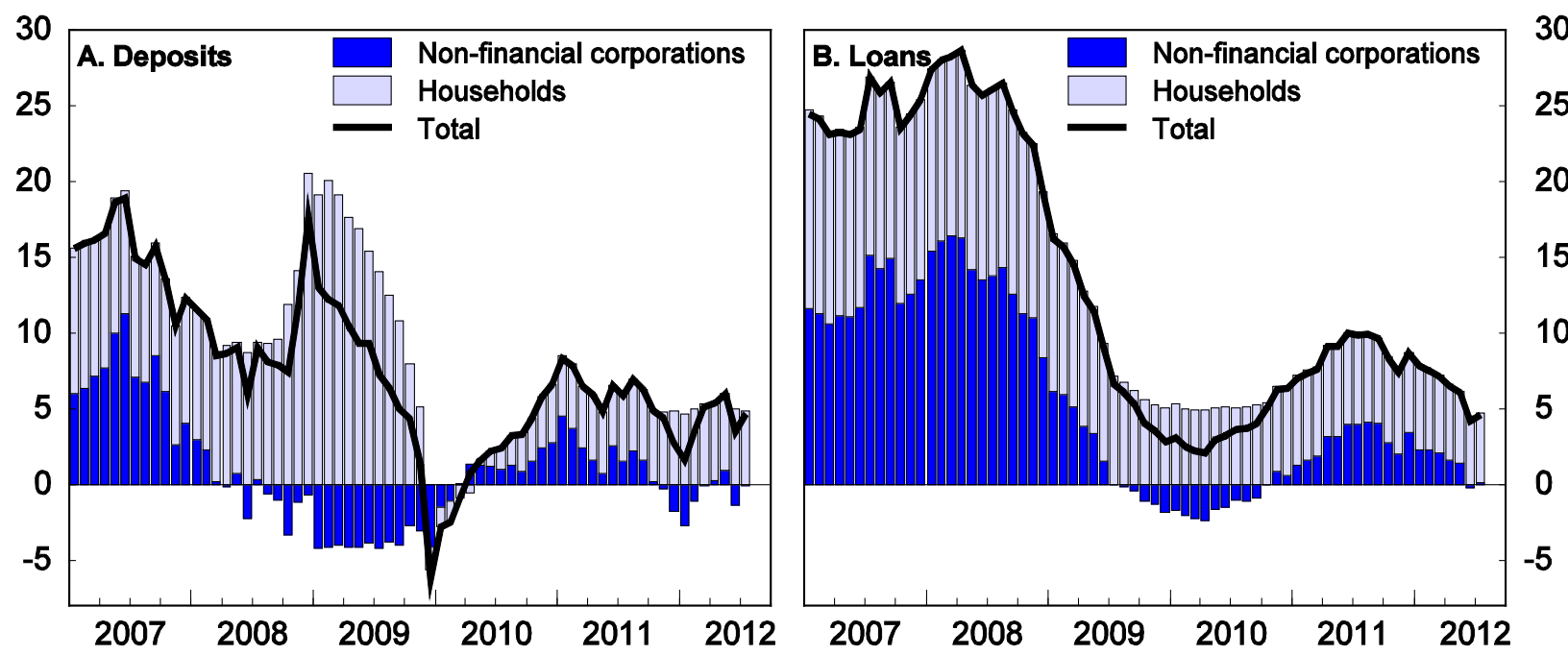

Figure 4. Contributions to the annual growth rate of private sector deposits and loans

In percentage points

Source: European Central Bank Data Warehouse.
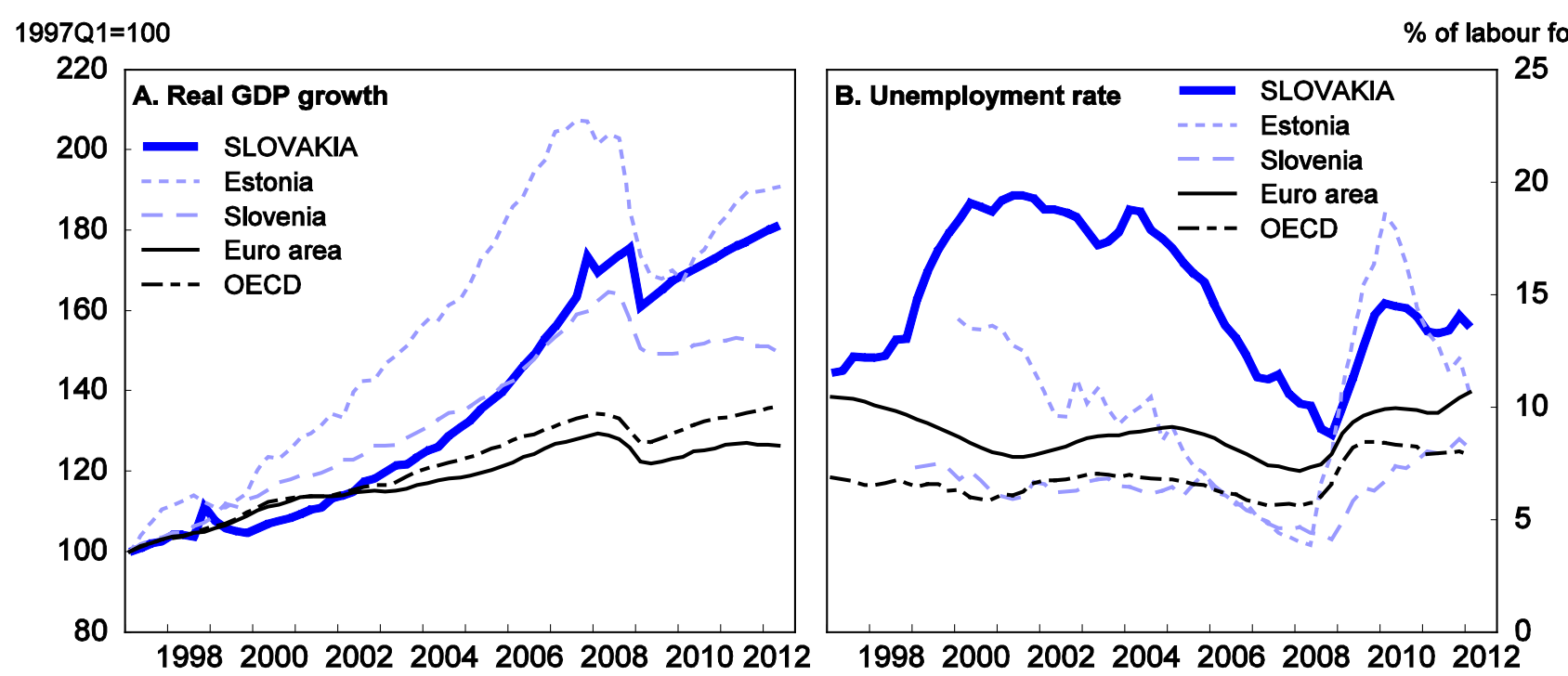

Figure 5. Real GDP growth and unemployment rate Source: OECD Economic Outlook database.

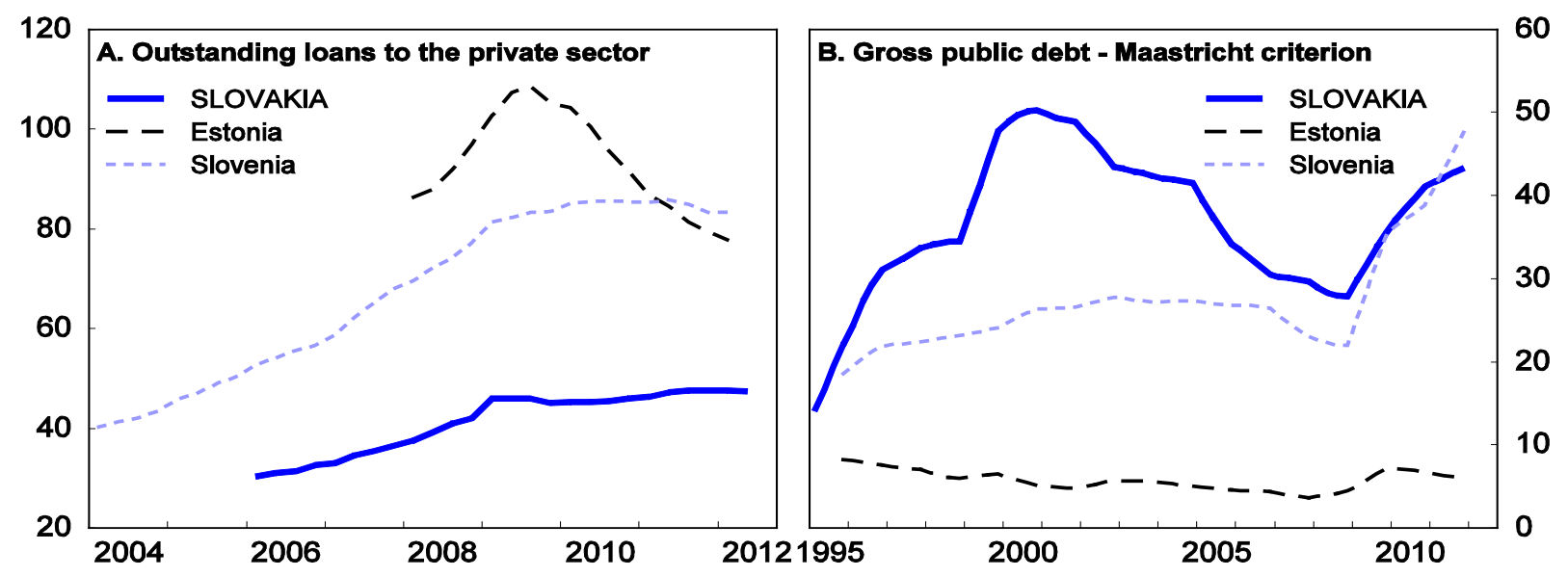

Figure 6. Private and public debt

In \% of GDP

Source: European Central Bank Data Warehouse; OECD Economic Outlook database. 
Table 1. Credits and deposits in Slovakia, 2007-2012

\begin{tabular}{lrrr}
\hline & $\begin{array}{r}\text { Total } \\
\text { credits }\end{array}$ & $\begin{array}{r}\text { Corporate } \\
\text { credits }\end{array}$ & $\begin{array}{r}\text { Household } \\
\text { credits }\end{array}$ \\
\hline Intercept & $25.078^{* * *}$ & $14.512^{* * *}$ & $9.960^{* * *}$ \\
& $(6.281)$ & $(5.650)$ & $(6.107)$ \\
& -0.019 & -0.116 & 0.145 \\
Deposit growth & $(-0.071)$ & $(-0.675)$ & $(1.329)$ \\
& & & \\
Crisis dummy & $-21.054^{* * *}$ & $-15.106^{* * *}$ & $-4.941^{* * *}$ \\
& $(-4.810)$ & $(-5.419)$ & $(-2.781)$ \\
$\begin{array}{l}\text { Interaction term crisis } \\
\text { and dps. growth }\end{array}$ & $0.858^{* * *}$ & $0.637^{* * *}$ & 0.148 \\
& & & $(1.353)$ \\
\hline
\end{tabular}

No. of obs.

67

67

67

Adjusted $\mathrm{R}^{2}$

0.923

0.912

0.919

Note: $*, * *$, and $* * *$ stands for significance at the $10 \%, 5 \%$, and $1 \%$ level, respectively. White-robust t-statistics in parentheses. Regression adjusted for autocorrelation of residuals (MA coefficient not reported).

The adoption of the euro in Slovakia happened after a long boom period, but just before the outbreak of the financial crisis. This timing was particularly advantageous in the sense that, the accession criteria (in particular the fiscal criteria) were easier to meet than for Estonia, which joined just one year later. Estonia had to implement a $10 \%$ fiscal consolidation package to keep the general government deficit in line with the euroaccession criterion. At the time of the accession monitoring period in Spring 2008, the benchmark Slovak 10 -year bond rate was still unaffected by the reassessment of sovereign risks, fiscal balances were still benefiting from the final stages of the boom and inflation was being restrained by two successive revaluations of the Slovak koruna.

Notwithstanding the positive effects of introducing the euro, the interaction of the crisis and the strong real appreciation in the run-up to joining the euro area, generated challenges which are still important for recent economic developments: First, the exchange rate was probably locked in at a too high level. Second, the focus of the fiscal policy on nominal targets to meet the Maastricht criteria meant that Slovakia possibly missed the opportunity to run a stricter fiscal course during the boom years. As a result, it inherited a pro-cyclical policy bias, which made fiscal expansion during the crisis particularly costly and painful to reverse. Third, the crisis radically changed the external environment of the highly export-dependent Slovak economy. Nevertheless, the early decision on euro adoption may have ensured that Slovakia faced the financial crisis with lower vulnerabilities than other countries. Euro membership also meant early participation in all collective crisis- related measures and hence much more financial and capital market stability (IMF, 2011).

Despite euro adoption, Slovakia has avoided a credit boom and bust scenario (Figure 6A). The main reason being the relatively cautious lending policy of banks before the crisis and that the outbreak of the crisis took place simultaneously with euro adoption . Slovenia (euro adoption in 2007) and Estonia (euro adoption in 2010 and currency board since the early nineties) experienced a rapid credit expansion before the crisis (Brixiova et al; 2010). For Estonia, and to a lesser extent Slovenia, strong deleveraging needs imposed a burden on the export-led recovery. By contrast, Slovakia recorded a relatively moderate increase in the ratio of credit to GDP, from 30 per cent in 2006 to 39 per cent in summer 2008 and immediately after the euro adoption, the credit share hiked further to 46 per cent in the first quarter of 2009. It then stagnated during the financial crisis, avoiding a strong deleveraging episode. Overall, credit development in Slovakia was not characterised by the accumulation of financial vulnerabilities to the same extent as in other emerging economies in Central and Eastern Europe (Fidrmuc and Hainz, 2010).

Slovakia achieved a substantial reduction in gross public debt during the preparations for the euro adoption (Figure 6B). Starting with a favourable public debt position of around 50 per cent of GDP in 2000, during the conversion process Slovakia reduced the debt level to only 28 per cent of GDP in 2008. However, the pressure on fiscal discipline was significantly reduced by euro adoption. Correspondingly, public expenditure revived as a response to the financial crisis and the debt to GDP ratio nearly reached its initial level, at 43 per cent. By contrast, fiscal developments in Slovenia were characterised by a smaller decline in debt prior to euro adoption, but a much steeper increase in public debt as a consequence of the crisis. Estonia, which entered the euro area only in 2010, after the financial crisis, has kept the public finances stable and below 3\% of GDP during the whole period.

\section{Exchange rate overvaluation}

The decade prior to the crisis were characterised by a rapid growth of GDP in Slovakia of around 6\%, about three times the euro area average. Rapid convergence came hand in hand with the strongest nominal and real appreciation among OECD member countries, outpacing the safe havens of Switzerland and Japan, as well as resource-rich globalisation winners like Canada and Australia. Inflation and unit labour cost growth above the euro area average contributed to nominal convergence and added to the real appreciation stemming from nominal appreciation. Currency revaluations accelerated this development shortly ahead of the crisis. As a result, the Slovak currency appreciated by nearly 30 per cent in real terms between 2006 and 2009 (Figure 7). The financial crisis was also accompanied by an external (price) competitiveness shock for Slovakia, because several neighbouring economies in Central Europe reacted to weaker external demand by strong competitive 
depreciations: the real effective exchange rate appreciated by a further 9 per cent in 2009, after the country had entered the euro area.

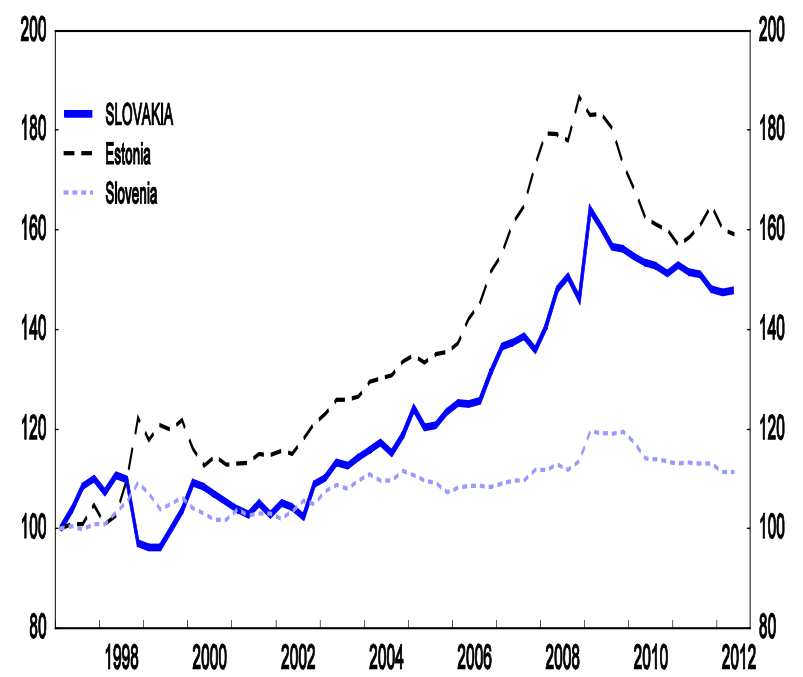

Figure 7. Real effective exchange rate based on unit labour costs

Indices, 1997Q1=100

Source: OECD Economic Outlook database.

While it is normal that a rapidly growing economy also experiences a real exchange rate appreciation, it may nevertheless be questioned whether the acceleration of appreciation immediately before the crisis would not have been reversed if the nominal exchange rate had not been fixed just at the outbreak of the crisis. Considering that regional peers had strongly depreciated their currencies by between 5\% (Czech Republic), 10\% (Hungary) and 20\% (Poland), it is not far-fetched to conclude that Slovakia entered the euro area with an exchange rate that turned out to be overvalued in the face of the crisis. This is not in contradiction with the IMF's (2012) assessment that Slovakia does not suffer from an external imbalance, because competitiveness has been restored via an endogenous adjustment, which has included wage restraint and productivity-increasing investment.

Since the euro adoption, real exchange rate movements have been determined mainly by the inflation and unit labour cost differentials vis-à-vis Slovakia's main trading partners. Actually, inflation has shown a relatively large degree of fluctuation in this period. The adoption of the euro arrested the earlier appreciation of the nominal euro exchange rate and related declines in import prices. Thus, domestic inflationary pressures were fully translated into rising inflation in the second half of 2008. However, the financial crisis exerted a strong downward pressure on inflation. Thus, inflation declined to less than 1 per cent in 2009 and 2010, below the average Balassa-Samuelson contribution to inflation because of the nominal convergence of non-traded goods prices. It could therefore be concluded that Slovakia came close to a state of "effective" deflation, with negative consequences for domestic demand. Simultaneously, wage increases decelerated dramatically from around 8\% before the crisis to less than 1\% in 2011.
Indeed, nominal price level convergence came to a halt in mid 2008. Contrary to other countries, labour productivity increased strongly after the crisis outperformed only by Estonia, helping to keep unit labour costs down and to reverse the excessive pre-crisis real appreciation to some extent.

Euro adoption changed the composition of the drivers of growth dramatically. Disinflation, enforced by the large output gap and increased unemployment, contributed to wage moderation and imposed a cap on job-rich domestic demand growth. Together with sizeable productivity increases, wage moderation allowed modest real exchange rate depreciation of about 2 per cent in 2010 and 2011, helping to prevent employment in manufacturing to fall more strongly, but not generating new employment. However, the pace of exchange rate depreciation was considerably slower than that of the appreciation before the crisis, indicating less capacity for internal devaluation than present in Estonia (Figure 7).

It is interesting to note that the development of the real exchange rate was similar before the crisis in Estonia and Slovakia, although in Estonia it was only driven by differences in unit labour costs and not by changes in the nominal exchange rate, while it was completely different for Slovenia (Figure 7). This pattern also corresponds to a different development of unemployment, which fell strongly in Estonia, stayed high in Slovakia and increased in Slovenia. Domestic demand in turn showed healthy growth in Estonia, stagnating growth in Slovakia and it appears to nose-dive in Slovenia (Figure 5).

\section{SPILLOVER EFFECTS FROM THE EURO AREA CRISIS}

\section{Trade and FDI linkages}

Tight trade linkages with Germany and other euro countries mean that growth shocks in those countries (often themselves being caused by external shocks, as in the case of Germany) are transmitted to Slovakia also via slower trade growth. The trade channel is further strengthened by strong financial links, including FDI. Slovakia is especially sensitive to developments in Germany and in the euro area, on which it has nearly the highest trade dependence (following Czech Republic, which is also an important trading partner of Slovakia) (IMF, 2012). Figure 8 shows that the weak economic performance of the euro area resulted in declining shares of this region in the exports of Slovakia and other new member states. These export market losses have only been partly compensated for by exports to more rapidly growing destinations outside the euro area.

It is interesting to note that the share of the euro area in Slovak trade started to decline before EU accession in 2005. It confirms that trade between CEECs and the existing EU member states was already at its potential level before the EU accession (Bussière et al., 2008). Moreover, the declining EU tarde shares of Eastern European euro entrants, cast doubt on the importance of the trade effects of a currency union, as 
intensively discussed in the literature (Frankel and Rose, 2002), but
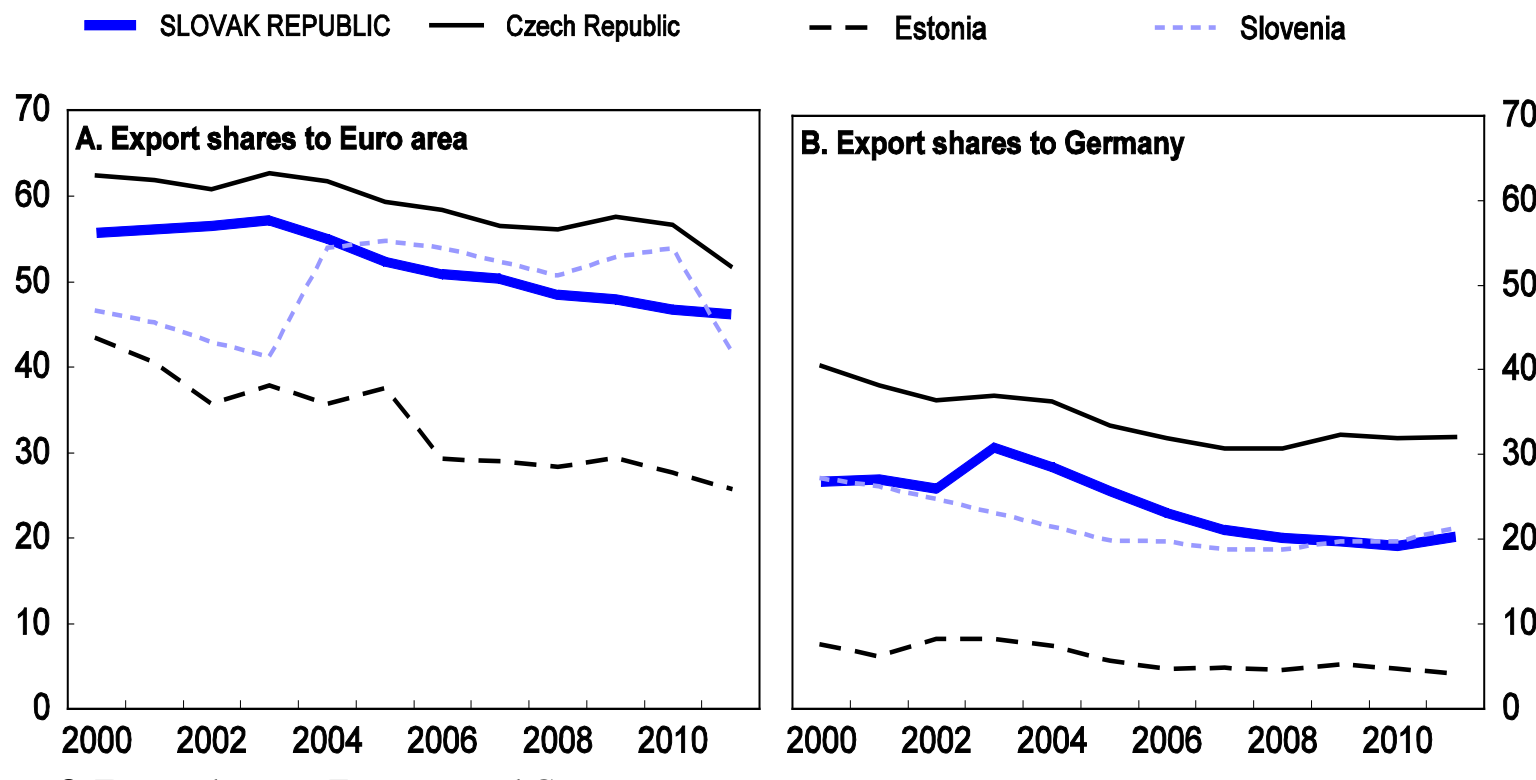

Figure 8. Export shares to Euro area and Germany

In per cent

Source: OECD, International Trade by Commodity Statistics (ITCS) database.

viewed rather sceptically before the Eastern enlargement of the euro area (Baldwin, 2006).

During the past decade, Slovakia has performed a successful restructuring strategy. Export industries have received special attention. Various measures were used to attract foreign direct investors, although this policy was efficient especially before the accession to the European Union. Most importantly, the automobile industry has become the most important exporting industry in Slovakia. The export share of the automobile industry doubled between 1997 and 2007 (to 20 per cent of total exports), but it was also subject to significant cyclical fluctuations. According to de Broeck et al. (2012), the reported improvements of exports were also strong in building fixtures and telecom equipment. The traditional export industries performed less well (iron and steel and footwear). With the exception of iron and steel, unit labour costs declined in all major export industries between 1998 and 2007. This is in line with the dominating importance of price competiveness for Slovak exports (Fabrizio et al., 2007).

However, this export-led growth strategy has also had its vulnerabilities (BUSSIERE et al., 2008). The Slovak economy has become strongly dependent on foreign demand, especially from Germany and the euro area. Business cycles in the industries concerned are often more pronounced than in other industries, especially services. As an example during the 2008/9 downturn the drop in demand was especially strong for automobiles, iron and steel, and building materials. Furthermore, the export industries that have expanded are mainly capital intensive, meaning that growth of production translated only marginally into a reduction of unemployment. The focus on large companies increases the mismatch on the Slovak labour market, which is characterized by large regional imbalances. A significant part of unemployment is located in more remote rural regions with a low population density. Last but not least, the rapid success of the export-led growth strategy was also achieved by a concentration on mobile industries which, though they could move in quickly, could also leave easily, meaning that a relatively minor worsening of business conditions or cost competitiveness can result in significant capacity outflows.

\section{Macroeconomic linkages}

The industrial mix in Slovakia is different from that of the euro zone, both because of the energy-intensity of the basic goods industries inherited from the central planning period and the concentration of foreign direct investment in specific export industries (such as the automobile sector and consumer electronics). As a consequence, the degree of co-movement of business cycles in Slovakia and the euro area is declining (Krugman, 1993, Kapounek and Poměnková, 2013).

Despite the significant real exchange appreciation in the run-up to euro adoption, Slovakia was among the most competitive new member states (de Broeck et al., 2012). The 2012 IMF Article IV examination concludes that Slovakia does not have an external competitiveness problem, although the repercussions of maintaining competitiveness with productivity increases in existing enterprises and wage restraint for domestic demand are not taken into account, thereby overestimating the underlying strength of export capacity.

Euro introduction has often been associated with a slight increase in prices, especially of day-to-day consumer products and services (Brachinger, 2008, 
Fluch and Stix, 2005). This increases the perceived inflation, even though overall inflationary effects remain small. Similar change-over effects were expected in Slovakia (Hüfner and Koske, 2008); however, the deflationary effects of the financial crisis generated a negative impact, which lowered inflation in Slovakia up to 2011.

Inflation accelerated again at the end of 2011 in a response to increasing energy and food prices, tax changes and rises in administrative prices. Inflationary pressures are likely to gain strength in the next recovery, which may not reduce the competitiveness of Slovak exports to the extent that wage determination has a strong plant-specific element and can thus be expected to respond to small competitiveness changes.

\section{Financial linkages and foreign financial institutions}

The financial sector is dominated by foreign-owned banks (based in Austria and Italy and to a lesser extent the Czech Republic and Belgium), which acquired stakes in the privatisation process and established their own networks (IMF, 2012). The deep integration of financial markets implies that shocks, such as the sovereign bond crisis, rapidly spill over to Slovakia. Banking conditions generally improved in 2011, reflecting the improving conditions of the Slovak economy. The direct exposure of Slovak banks to foreign assets is rather low, but they can be affected through the impact of sovereign risk crises on their parent banks in case of some euro area countries. Similarly, Slovak government bonds represent a large share of bank securities portfolios (IMF, 2011). This can be a source of financial risks, if contagion effects are transmitted to Slovakia. The main challenge is therefore, to avoid the slightest risk of default, which could trigger an immediate shutdown of access to financial markets.

Bond spreads increased during the crisis due to a general increase in risk aversion. Credit ratings have also been affected by the countries' contributions to rescue funds (a major justification for the recent across-theboard S\&P downgrade). Slovak bond spreads increased significantly from mid 2011 (by 328 basis points compared to Germany in December 2011, the seventh highest spread in the euro area) and Slovakia was downgraded by Standard \& Poor's and Moody's at the beginning of 2012. Despite the downgrading, bond spreads remained constant and even decreased slightly in the spring of 2012 (Figure 9). Moreover, the increase in Slovak government bond rates remained below that experienced by Slovenia. Finally, despite new hikes of government bond rates in Spain in summer 2012, Slovak government bond rates have remained constant, which indicates a certain degree of market confidence.

At the beginning of 2012, two rating agencies downgraded the long-term sovereign credit rating of the Slovak Republic, Standard \& Poor's from A+ to A Moody's from A2 to A1. These actions were a part of a broad downgrading of nine European countries by both rating agencies (but not by Fitch). The downgrade for Slovakia was explained partially by uncertainties regarding the development in the euro area and its impact on the Slovak economy. Behind these factors, OECD analysis of ratings in emerging economies showed that the rating for Slovakia corresponded relatively closely to the level implied by the standard fundamentals (macroeconomic developments and institutional and political risks) (OECD, 2010a). In particular, low inflation, low public debt and output growth were the main determinants of the advantageous rating of Slovakia. In turn, OECD (2010a) pointed to political risk and institutional effectiveness as the main areas of weakness. Actually, all factors stressed by this analysis have worsened recently. This confirms that Slovakia has to strengthen its institutional reform in order to maintain its ratings.

$\%$

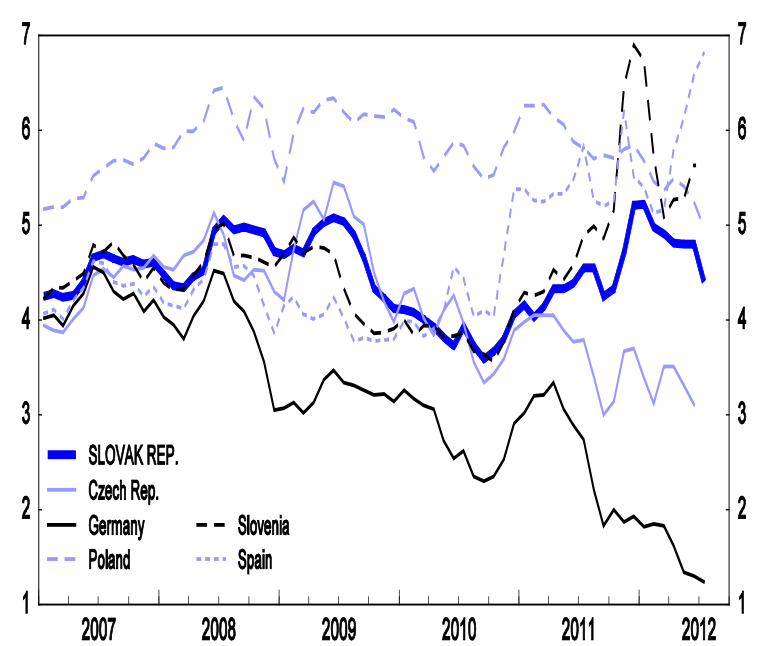

Figure 9. 10 year-government bond rates Source: OECD Economic Outlook database.

Lending conditions, notably in the case of Slovakia's fully foreign-owned banking sector, increasingly depend on the situation of the banking sector in countries from which the parent banks originate (mainly Austria, but also Belgium, Germany, Italy, Netherlands). ${ }^{1}$ Figure 10 shows the importance of foreign owned banks in the banking system and its impact on economic development. The high degree of co-movement between Austrian, Italian and Slovak credit growth, confirms that credit growth is driven by the situation in the parent banks. In particular, credit growth rates reached 30 per cent annually before the financial crisis, this being about four times higher than in Austria. However, credit growth rates dropped to about 5 per cent in both countries in 2010. The difference between Slovak and the source-country, is that the credit developments increased only slightly in the past year, which confirms the role of source country factors.

\footnotetext{
${ }^{1}$ In 2009 , around $86 \%$ of all banks assets were controlled by the Erste Group Bank (21\% Austria), Intesa San Paolo (19\% Italian), Raiffeisen Zentralbank (17\% Austria), KBC Bank (11\% Belgium), Unicredit (6\% Italy), Dexia (5\% Belgium and France), OTP (3\% Hungary), Volksbank (3\% Austria) and ING (1\% Netherlands) (IMF, 2011Article IV).
} 
Correlation analysis confirms these findings. Before the financial crisis, Slovak credit growth reported a medium degree of correlation (0.6) with the source countries (except for Italy with negative correlation). After the financial crisis, the correlation increased to 0.9 between Slovakia and Austria, while it remained largely unchanged for the other countries.

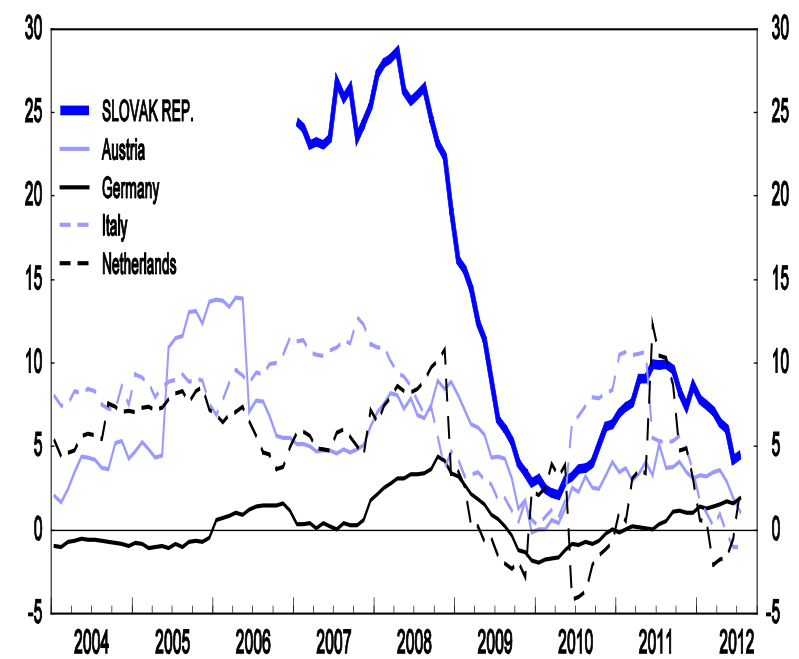

Figure 10. Loans to private non-monetary financial institutions

Year-on-year percentage change

Source: OECD Economic Outlook database.

Moreover, this finding is confirmed if we estimate output elasticity of credits for individual Slovak banks. We use Bankscope data for 21 banks between 1997 and 2011 (latest available data). The sensitivity analysis look at the top 10 banks (Slovenská sporitel'ňa, Všeobecná Úverová Banka, Tatra Banka, Československá obchodná banka, UniCredit Bank Slovakia, Poštová Banka, Prvá Stavebná Sporitel'ňa, Prima banka Slovensko, VOLKSBANK Slovensko, and OTP Banka Slovensko) in Slovakia. We use a fixed effect model with cross-section SUR standard errors,

$$
\begin{gathered}
\log (k)_{t}=\mu_{i}+\beta_{1} \log \left(g d p_{i t}^{\text {precrisis }}\right)+\beta_{2} \log \left(g d p_{i t}^{\text {crisis }}\right) \\
+\beta_{2} \log \left(g d p_{i t}^{\text {postcrisis }}\right)+\varepsilon_{t}
\end{gathered}
$$

This relationship can also be interpreted as a long-run relationship, although we do not test for panel cointegration due to short time series. Table 2 shows that there was a strong interdependence between credits and output before the crisis, which has become insignificant since the financial crisis.

\section{CONCLUSIONS}

Domestic sources of growth are not well developed in Slovakia. Spending for innovation purposes is low and the interaction between domestic knowledge producers and the economy is weak. Regional mobility is low and regional differences in labour market performance are high. Social housing is not geared towards regions with a growing employment potential (Findrmuc and Senaj, 2014). Capital market financing of business start-ups is underdeveloped. The financial sector is dominated by foreign banks. The lending of the financial sector is restricted to the local deposit base, which may become a constraint once a new growth cycle sets in. Consumption and mortgage financing are overrepresented. The green growth potential is far from fully utilised (OECD, 2010b).

\section{Table 2. Disconnection of credit development from output in Slovakia}

(Estimated income elasticities for subperiods)

\begin{tabular}{lrr} 
& All banks & Top 10 banks \\
\hline Pre-crisis (1997-2007) & $3.119^{* * *}$ & $2.944^{* * *}$ \\
& $(3.898)$ & $(3.017)$ \\
Crisis (2008-2009) & 1.046 & 1.598 \\
& $(1.079)$ & $(1.249)$ \\
Post-crisis (2010-2011) & 1.587 & 0.868 \\
& $(0.824)$ & $(0.415)$ \\
\hline No of banks & 21 & 10 \\
No of obs & 174 & 0.106 \\
Adjusted $\mathrm{R}^{2}$ & 0.042 & \\
$\begin{array}{l}\text { Note: } * \text { **, and *** stands for significance at the } 10 \%, 5 \%, \\
\text { and 1\% level, respectively. } t \text {-statistics in parentheses. }\end{array}$
\end{tabular}

The jobless recovery in Slovakia follows the general recovery pattern after a financial crisis (Calvo et al., 2012). The growing risk aversion of lenders increases the ratio of the collateral value of the loan, this in turn favours capital intensive investment projects in existing enterprises. Maintaining the employment level during a financial crisis would therefore require a larger wage adjustment than what would follow from the cyclical response of wages to increasing unemployment. The consequence of reduced lending by the financial sector is a combination of wage and job restraint. This underlines the importance of a sound financial sector for the recovery from a financial crisis.

Before the financial crisis, credit growth in Slovakia was lower than in other CEECs. Despite of this, it further slowed Slovakia at the end of 2011, as the sovereign debt crisis escalated and credit standards were tightened, in particular for consumer credit and real estate mortgages. A growing segmentation of financial markets within the EMU has caused lending to closely follow the development of deposits since the financial crisis. Thus, the financial crisis reduced possible gains from financial integration, which was one of the motives for the euro membership.

Acknowledgments: The authors maintain the full responsibility for the content, which is not necessarily shared by the OECD Secretariat or its member countries. The authors are grateful to Caroline Klein, Robert Price, Robert Ford and Camille Amling for comments on an 
earlier draft, Beatrice Guerard for statistical assistance and Josiane Gutierrez for secretarial assistance.

\section{REFERENCES}

BACKÉ, P., WÓJCIK, C., (2008). Credit booms, monetary integration and the new neoclassical synthesis, Journal of Banking and Finance 32(3), pp. 458-470. http://dx.doi.org/10.1016/j.jbankfin.2007.07.005

BALDWIN, R. (2006). 'The euro's trade effects', Working Paper No. 594, ECB, Frankfurt.

BARISITZ, S. 2011. Nonperforming Loans in CESEE What Do They Comprise? Focus on European Economic Integration No. 4, Oesterreichische Nationalbank, 46-68, http://www.oenb.at/de/img/feei_2011_q4_studies_1_tcm 14-241680.pdf

BASSO, H. S., O. CALVO-GONZALES, JURGILAS, M. (2011), Financial dollarization and the role of foreign-owned banks and interest rates. Journal of Banking and Finance 35(4), 794-806. http://dx.doi.org/10.1016/j.jbankfin.2010.11.018

BECKMANN, E., FIDRMUC, J., STIX, H., (2012), Foreign Currency Loans and Loan Arrears of Households in Central and Eastern Europe. Working Paper No. 181, Oesterreichische Nationalbank, Vienna. BERKA, M., DEVEREUX, M. B., ENGEL CH. (2012), "Real Exchange Rate Adjustment in and out of the Eurozone", American Economic Review: Papers \& Proceedings 102, (3), 179-185. http://dx.doi.org/10.1257/aer.102.3.179

BRACHINGER, HANS WOLFGANG, (2008). "A new index of perceived inflation: Assumptions, method, and application to Germany," Journal of Economic Psychology, Elsevier, vol. 29(4), pages 433-457, August. http://dx.doi.org/10.1016/j.joep.2008.04.004

BRIXIOVA, Z., L. VARTIA AND A. WÖRGÖTTER, ANDREAS (2010). "Capital flows and the boom-bust cycle: The case of Estonia," Economic Systems, Elsevier, vol. 34(1), 55-72, March. http://dx.doi.org/10.1016/j.ecosys.2009.11.002

BRIXIOVA, Z., MORGAN, M. AND WÖRGÖTTER A. (2009), "Estonia and Euro Adoption: Small Country Challenges of Joining EMU", OECD Economics Department Working Papers, No. 728, OECD Publishing. doi: : 10.1787/220860037027

BUSSIERE, M., FIDRMUC, J. SCHNATZ, B. (2008). EU Enlargement and Trade Integration: Lessons from a Gravity Model. Review of Development Economics 12(3), 562-576. http://dx.doi.org/10.1111/j.14679361.2008.00472.x

CALVO, G., A., F. CORICELli, P. OTTONELlO (2012), The Labour Market Consequences of Financial Crises with or without Inflation: Jobless and Wageless recoveries, NBER Working Paper 18480.

DE BROECK, M., MEHREZ, G., GUSCINA, A. (2012). Assessing Competitiveness Using Industry Unit Labor Costs: an Application to Slovakia, Working Papers 12/107, International Monetary Fund, http://www.imf.org/external/pubs/ft/wp/2012/wp12107.p df
ÉGERT, B. (2011). Catching-up and inflation in Europe: Balassa-Samuelson, Engel's Law and other culprits. Economic Systems 35(2), 208-229.

FABRIZIO, ST., IGAN D. AND MODY A. (2007), The Dynamics of Product Quality and International Competitiveness, Working Paper 07/97, International Monetary Fund, http://www.imf.org/external/pubs/ft/wp/2007/wp0797.pd f

FIDRMUC, J., HAINZ, C. (2010). Default rates in the loan market for SMEs: Evidence from Slovakia.

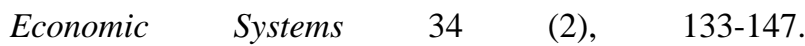
http://dx.doi.org/10.1016/j.ecosys.2009.10.002

FIDRMUC, J., SENAJ, M. (2014). Income, Schooling and Housing Wealth during Economic Reforms, Czech Journal of Economics and Finance/ Finance a úvěr 64 (2), 160-176.

FLUCH, M., STIX, H. (2005): Perceived Inflation in Austria - Extent, Explanations, Effects. In: Monetary Policy \& the Economy, Q3/05, pp. 22-47. Vienna: Oesterreichische Nationalbank. http://www.oenb.at/en/img/mop_2005_q3_analysis2_tc m16-34757.pdf

FRANKEL, J., ROSE, A. (2002). An estimate of the effect of common currencies on trade and income. Quarterly Journal of Economics, 117, 437-466. http://dx.doi.org/10.1162/003355302753650292

HÜFNER, F. AND KOSKE, I. (2008). The Euro Changeover in the Slovak Republic: Implications for Inflation and Interest Rates, OECD Economics Department Working Papers, No. 632, OECD Publishing. doi: $10.1787 / 240631807010$

IMF (2011). Slovak Republic: 2011. Article IV Consultation-Staff Report; Informational Annex; and Public Information Notice on the Executive Board Discussion, Country Report No. 11/122, IMF Washington,

http://www.imf.org/external/pubs/ft/scr/2011/cr11122.pd f

IMF (2012). Slovak Republic: 2012 Article IV Consultation-Staff Report; http://www.imf.org/external/pubs/ft/scr/2012/cr12178.pd $\underline{\mathrm{f}}$

KAPOUNEK, S., POMĚNKOVÁ, J. (2013). The endogeneity of optimum currency area criteria in the context of financial crisis: Evidence from the timefrequency domain analysis. Agricultural Economics/Zemědelská ekonomika 59, (9), 389-395.

KOSKE, I. (2009), "Achieving Fiscal Flexibility and Safeguarding Sustainability: The Case of Slovakia", OECD Economics Department Working Papers, No. 681, OECD Publishing. doi: $10.1787 / 226231818862$

KRUGMAN, P. (1993). Lessons of Massachusetts for EMU, In: Torres, F., Giavazzi, F. (Eds): Adjustment and Growth in the European Monetary Union, Cambridge: Cambridge University Press.

LEVY YEYATI, E. (2006), Financial dollarization: Evaluating the consequences. Economic Policy 21(45), 61-118. 
LUCA, A., PETROVA, I. (2008). What Drives Credit Dollarization in Transition Economies? Journal of Banking and Finance, 32, 858-869. http://dx.doi.org/10.1016/j.jbankfin.2007.06.003

OECD (2010a). Annex 2.A1, Estimated models for EMBI spreads and credit ratings, OECD Economic Surveys, Turkey, OECD Paris, 96-99.

OECD (2010b). Economic Surveys: Slovak Republic, Paris.

OECD (2012a). Economic Outlook No. 91, Paris

OECD (2012b). Economic Surveys: Slovak Republic, Paris.
OOMES, N. (2005). Maintaining Competitiveness Under Equilibrium Real Appreciation: The Case of Slovakia, IMF Working Papers 05/65, International Monetary Fund.

UNICREDIT, (2012). Banking in CEE: The new normal. CEE Banking Outlook, January 2012, http://www.bankaustria.at/informationspdfs/CEE_Banki ng Outlook 10012012_13h.pdf

WALCH, N., WÖRZ, J. (2012). The Impact of Country Risk Ratings and of the Status of EU Integration on FDI Inflows in CESEE Countries, Focus on European Economic Integration Q3/12, 8-26. 